\title{
Epidemiology of Bonamia in the UK, 1982 to 2012
}

\author{
I. Laing, P. Dunn, E. J. Peeler, S. W. Feist", M. Longshaw \\ Cefas, Weymouth Laboratory, Barrack Road, The Nothe, Weymouth, Dorset DT4 8UB, UK
}

\begin{abstract}
Bonamiasis, caused by Bonamia ostreae, was confirmed in native flat oysters Ostrea edulis L. in England in 1982. Hudson \& Hill (1991; Aquaculture 93:279-285) documented investigations into the initial spread of the disease in wild and cultivated stocks of native oysters in the UK. They also described the controls that were initially applied to prevent the further spread of the pathogen. This paper reports on subsequent controls and associated monitoring applied in the UK and reports on the epidemiology of the disease in the $30 \mathrm{yr}$ from 1982 to 2012. Bonamiasis remained confined to the zones in England as documented by Hudson \& Hill (1991) until 2005, when it was confirmed in Lough Foyle, Northern Ireland. In 2006 it was found in 2 new areas, one in Wales and one in Scotland. Subsequent further spread to additional areas in all parts of the UK has resulted in 9 zones being currently designated as infected with the disease. In addition, a single oyster from one area has tested positive for the closely related $B$. exitiosa. In general, analysis of the results of the monitoring programme in England and Wales shows no clear trend in infection levels over time, although there has been an apparent decrease in the level of infection in some fishery areas. In an autumn sampling programme the highest levels of infection were detected in October.
\end{abstract}

KEY WORDS: Bonamia ostreae $\cdot$ Epidemiology $\cdot$ Prevalence $\cdot$ Monitoring $\cdot$ Introduction $\cdot$ Spread Legislation

\section{INTRODUCTION}

The haplosporidian parasite Bonamia ostreae (OIE 2012 ) is the causative agent of bonamiasis, which is capable of causing severe mortalities of native European flat oysters Ostrea edulis. The impact of infection is evidenced by the drastic $(93 \%)$ drop in recorded production of $O$. edulis in France, from $20000 \mathrm{t} \mathrm{yr}^{-1}$ in the early 1970 s to $1400 \mathrm{t}$ in 1982 (FAO data) following the occurrence of the disease, although infection with Marteilia refringens is also implicated in this decline (Alderman 1979).

Hudson \& Hill (1991) documented the initial introduction, impact and spread of bonamiasis in England. They noted that it was first confirmed in England in wild stocks of Ostrea edulis in the River Fal, Cornwall, in 1982. In the same year it was also detected in Essex and in 1983 in the Helford River. By 1986, they showed that bonamiasis was found to have further spread to Poole (harbour and bay), the Solent and its adjacent south coast harbours.

Further spread of the disease at the time was successfully prevented by controls on movements of live shellfish made under the Molluscan Shellfish (Control of Deposit) Order 1974. This legislation recognised 3 separate bonamiasis-infected zones in the southwest, south and southeast of England (Hudson \& Hill 1991). The reference to zones in the text is to a geographical unit of one or more contiguous hydrological areas defined by the diseases status. Each of these areas will comprise one or more sampling sites (farm or fishery location).

It is useful to consider the legislative background to the information on bonamiasis collected and presented in this paper as this influenced the monitoring. A change in the legislation controlling movements of live shellfish for re-laying became necessary with the coming of the Single European Market 
to the UK in 1993. Movements of shellfish into the UK continued to be controlled because the UK was able to apply for Approved Zone status for listed molluscan diseases, i.e. Marteilia refringens at Member State level and Bonamia ostreae free zones. Initially only bivalve molluscan shellfish originating from areas of equal or higher health status could be introduced into proposed Approved Zones, although the rules were later relaxed for species that were not susceptible to these diseases. An annual programme of sampling and testing from 1993 onwards, as described below, of Ostrea edulis as the susceptible species to bonamiasis and marteiliosis was carried out in support of the application for and maintenance of Approved Zone status, which was not officially granted until 2002 (Commission Decision 2002/ 300/EC). More recently, new aquatic animal health legislation has been agreed by all the EU Member States (Council Directive 2006/88/EC and Commission Regulation [EC] No 1251/2008) and transposed into UK national legislation. Regular and routine sampling and testing for maintenance of disease-free status for marteiliosis was no longer required, provided that effective controls on movements were in place, and so a much reduced monitoring programme was initiated from 2008 onwards. Subsequent to the official confirmation (OIE 2011) of marteiliosis in a sample of mussels from the River Tamar in 2011 the monitoring has once again increased slightly. Sampling has also been (and continues to be) carried out in response to reported unusual mortality.

The 1993-2007 programme in support of Approved Zone status for marteiliosis entailed regular sampling from all of the areas within the bonamiasis-infected zones. As all samples are examined by histological methods to give a complete examination of any pathology, this together with results from previous and subsequent sampling efforts, enabled an assessment to be made of the status of bonamiasis in the 3 infected zones during at least the $15 \mathrm{yr}$ period of this programme and in some cases longer. An analysis of this information is presented in this paper, which includes data on outbreaks of bonamiasis in 7 new areas in England, Wales and Northern Ireland since 2005.

\section{MATERIALS AND METHODS}

Following the first occurrence of bonamiasis disease in the UK in 1982, in the Fal estuary, the initial sampling programme in England and Wales was designed to determine geographic spread of the disease with the movement and deposit of live oysters from known and suspected infected sites, together with a need to respond to reports of unusual mortality.

From 1993 to 2007 inclusively an extensive planned programme of sampling and testing of flat oysters was undertaken for the reasons described above. Oysters were obtained from shellfish farmers and fishermen in all sites around the UK coast where this species occurred in sufficient numbers. Two samples (spring and autumn) were taken each year in areas free of bonamiasis and marteiliosis and one sample (autumn) in the various areas infected with bonamiasis but free of marteiliosis. The Official Services in Scotland, Northern Ireland and England and Wales were responsible for collection and testing of samples. The level of statistical confidence required for the survey dictated the number of animals required. In the initial application period of $2 \mathrm{yr}, 150$ animals per site were tested by histological methods (see remainder of this section), giving a $95 \%$ probability of detecting disease if it were present at $\geq 2 \%$ prevalence in the population (assuming a perfect test). Histology is the 'gold standard' diagnostic method for the diagnosis of Bonamia ostreae; it has good sensitivity for moderate to high intensity infections but low sensitivity for low intensity infections. Specificity is low since the technique cannot discriminate between Bonamia species. Once this initial survey had been completed, a lower level of confidence, requiring only 30 animals per site satisfied the legislation (91/67/ EEC as amended by 95/22/EC).

In Scotland, usually between 6 and 10 areas were sampled each year from both wild and cultivated stocks, taking samples of 30 oysters from each area, although in the first few years (1993 onwards) of monitoring up to 25 samples, each of 150 oysters, were obtained. In Northern Ireland, 7-8 samples were taken each year from sites within loughs with wild stocks of native oysters to give a total of 150 oysters from 1993 to 2001, and 30-60 oysters thereafter.

In England and Wales, samples were collected from a total of 145 sampling sites in 26 hydrological areas. The number of sites per area ranged from 1 to 30 (median $=3.5)$. Sixty-eight sites were classified as farmed sites and 76 sites as fisheries (see Table 2). During the planned monitoring programme (19932007) there were several suitable sites in many areas, and wherever possible these were sampled in rotation, usually over a 2 to 3 yr period. There were some sites in some areas infected with bonamiasis where sampling was carried out in the autumn every year, 
providing a continuous record of the levels of infection in these areas. The number of samples obtained for the 1993-2007 spring sampling programme was dictated by availability of flat oysters in areas still free of bonamiasis. Usually about 5-8 samples (of 30 or 150 oysters) were obtained each year from each sampling site.

Spring samples were usually taken between March and June inclusive and the autumn samples in the period September to December inclusive. The data on prevalence and intensity of infection presented are predominately from the results from the autumn samples, unless spread to a new area is noted.

Oysters collected from each site in England and Wales were submitted to the Cefas Weymouth Laboratory in cool boxes containing ice blocks. Samples were normally of marketable size stock, although no size measurements were recorded. When samples could not be processed on the day of delivery, the oysters were chilled overnight in a commercial fridge at approximately $4^{\circ} \mathrm{C}$. Oysters were opened using an oyster knife, whilst ensuring minimal damage to the soft tissues. A 3-4 mm section through the main body of the oyster encompassing digestive gland, gonad and gills was taken and fixed in Davidson's seawater fixative for a minimum of $24 \mathrm{~h}$ before transfer to $70 \%$ industrial methylated spirits. Tissues were processed to wax blocks using an automatic vacuum infiltration tissue processor. Sections were cut at 3 to $5 \mu \mathrm{m}$ and adhered to a glass microscope slide. Samples collected between 1993 and 2000 inclusively were routinely stained using Gomori's trichrome stain. Samples processed from 2001 to 2007 were stained using haematoxylin and eosin (H\&E). Both staining techniques provided good resolution of histopathology and of Bonamia ostreae parasites, as well as concomitant parasite infections if present. Gomori was the staining technique used for assessment of disease presence (including bonamiasis) that was widely used for several years as an alternative to H\&E. It is a technique that was originally designed to show connective tissues as well as other structures (Gomori 1950). Stained slides were examined on a light microscope using bright field illumination. Individual sections were examined at a range of magnifications and notes made of the presence of pathological changes and parasites in tissue sections. In particular, note was made of any animals infected with Bonamia sp. In dubious cases, additional sections were examined. Infection levels in oysters collected from 2003 to 2007 inclusive were assessed from stained tissue sections according to a grading system ranging from 0 (uninfected) to 3 (heavy infection) (Table 1). Compared with the scoring technique adopted by Diggles et al. (2003) for comparison of heart imprints, histology and in situ hybridisation for $B$. exitiosus, our approach used fewer categories for the level of infection, i.e. 3 rather than 5, since we found that a simpler system was easier to apply during routine diagnosis.

\section{RESULTS}

A list of all the areas in England and Wales sampled in the spring and autumn monitoring programmes, together with a summary of monitoring of the sites within these areas, is given in Table 2 . Infected populations were found at 100 sites (54 farmed sites and 46 fishery sites) in 17 of the 26 areas. In these areas, the percentage of sites where infection was found one or more times over the sampling period varied from $100 \%$ (in 10 areas) to $25 \%$ (in one area). Approximately $69 \%$ of all 145 sites and $76 \%$ of the 131 sites in known infected areas tested positive. Table 2 does not include results that were presumptive, due to unconfirmed observations in additional histological sections or in further samples from the same site. There was a strong contrast in the site prevalence between some of the larger areas. In the Solent, only 11 of 30 sites ( 7 of the 26 fishery sites and all 4 farm sites) tested positive compared with the Blackwater and the Fal, where all 25 sites and 17 of 18 sites, respectively, were found to be infected at

Table 1. Grading system used to assess intensity of Bonamia infections in oysters examined by histology between 2003 and 2007

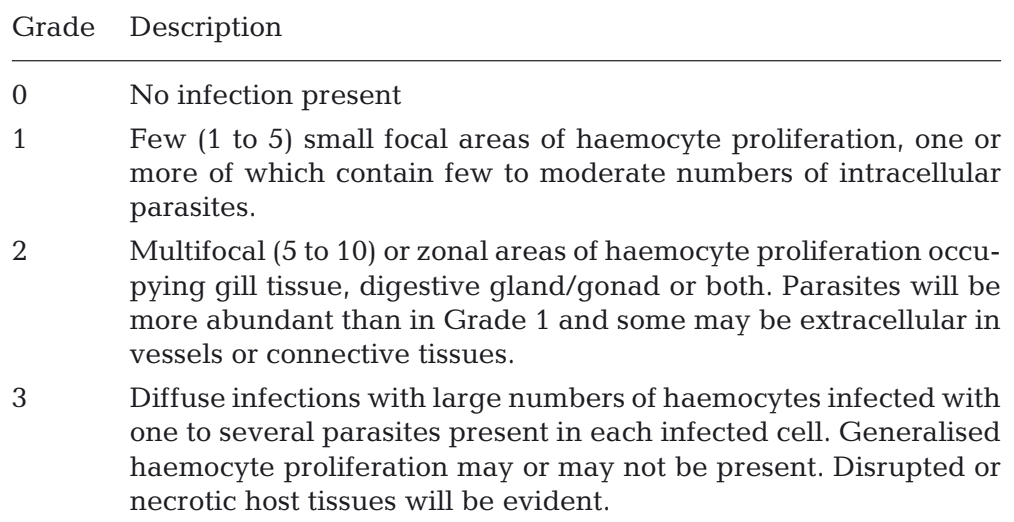

1 Few (1 to 5) small focal areas of haemocyte proliferation, one or more of which contain few to moderate numbers of intracellular parasites.

2 Multifocal (5 to 10) or zonal areas of haemocyte proliferation occupying gill tissue, digestive gland/gonad or both. Parasites will be more abundant than in Grade 1 and some may be extracellular in vessels or connective tissues.

3 Diffuse infections with large numbers of haemocytes infected with one to several parasites present in each infected cell. Generalised haemocyte proliferation may or may not be present. Disrupted or necrotic host tissues will be evident. 
Table 2. Farm and fishery sites in England and Wales sampled for Bonamia, 1982 to 2012

\begin{tabular}{|c|c|c|c|c|c|}
\hline \multirow{2}{*}{ Hydrological area } & \multirow[b]{2}{*}{ Farmed } & \multicolumn{3}{|c|}{ Sampling sites } & \multirow[b]{2}{*}{$\begin{array}{c}\text { Years } \\
\text { sampled }\end{array}$} \\
\hline & & Fishery & Total & $\begin{array}{l}\text { Testing } \\
\text { positive }\end{array}$ & \\
\hline 1. Holy Island & 1 & & 1 & 0 & 4 \\
\hline 2. Brancaster & 1 & & 1 & 0 & 7 \\
\hline 3. River Blyth/Alde & 2 & & 2 & 0 & 7 \\
\hline 4. Walton Backwaters & 2 & 1 & 3 & 3 & 20 \\
\hline 5. River Colne & 3 & & 3 & 2 & 13 \\
\hline 6. River Blackwater & 16 & 9 & 25 & 25 & 24 \\
\hline 7. River Crouch/Roach & 5 & 1 & 6 & 6 & 16 \\
\hline 8. South Thames & 3 & 1 & 4 & 1 & 22 \\
\hline 9. Chichester Harbour & 1 & 4 & 5 & 5 & 19 \\
\hline 10. Langstone Harbour & & 3 & 3 & 3 & 15 \\
\hline 11. Portsmouth Harbour & 2 & 4 & 6 & 6 & 16 \\
\hline 12. The Solent & 4 & 26 & 30 & 11 & 24 \\
\hline 13. Poole Bay & & 2 & 2 & 2 & 17 \\
\hline 14. Poole Harbour & 9 & & 9 & 9 & 22 \\
\hline $\begin{array}{l}\text { 15. Portland Harbour } \\
\text { and The Fleet }\end{array}$ & 3 & 2 & 5 & 2 & 7 \\
\hline 16. River Dart & 1 & & 1 & 0 & 4 \\
\hline 17. River Avon & 1 & & 1 & 0 & 2 \\
\hline 18. River Yealm & 1 & & 1 & 0 & 2 \\
\hline 19. Plymouth Harbour & 1 & 1 & 2 & 2 & 5 \\
\hline 20. River Fowey & & 1 & 1 & 0 & 11 \\
\hline 21. River Fal & 6 & 12 & 18 & 17 & 24 \\
\hline 22. River Helford & 1 & 1 & 2 & 2 & 16 \\
\hline 23. Swansea Bay & & 4 & 4 & 0 & 16 \\
\hline 24. River Cleddau & & 4 & 4 & 3 & 14 \\
\hline 25. Menai Strait & 4 & & 4 & 1 & 19 \\
\hline 26. Morecambe Bay & 2 & & 2 & 0 & 10 \\
\hline Total & 69 & 76 & 145 & 100 & - \\
\hline
\end{tabular}

The prevalence of infection (in all samples, where at least one animal tested positive) varied from 0.04 to $74 \%$, with a mean of $11.78 \%$ (median $6.90 \%$ ). The distribution was skewed to the right (Fig. 1A) and the prevalence in $58 \%$ of samples was $10 \%$ or less, but a small number of populations were heavily infected $(8 \%$ of samples had a prevalence greater than $30 \%$ ). When prevalence distribution is broken down by area type (fishery versus farmed; Fig. 1B) it becomes clear that fishery areas are more likely to have low observed prevalence $(\leq 10 \%)$ and less likely to have prevalence $>15 \%$ compared with farmed areas.

An assessment of trends within the 3 infected zones representing the main production areas in the UK was made.

\section{Southwest England (Areas 17-22)}

In 1991, the Fal and Helford river estuaries were the only areas known to be infected in this part of the UK. Sampling in 1993 revealed that native flat oysters collected from Plymouth least once. During the 1993 to 2007 monitoring period, none of the sites tested in the Solent were found positive in 6 years; by contrast, on the Fal and Blackwater at least one site tested positive in every year. The average prevalence of infected sites on the Blackwater was considerably higher than infected sites in the Solent or Fal $(15.5 \pm 1.3 \%$ compared with $7.9 \pm 1.6 \%$ and $9.6 \pm 0.7 \%$, respectively).

From 1982 to 2012, over 76000 oysters in 1175 samples were examined by histology (Table 3 ). The average prevalence at infected sites was $9.31 \%$ (ranging from $2.4 \%$ in 1982 to $16.0 \%$ in 1986). Farmed sites had a higher average prevalence compared with fishery sites $(12.8 \pm 0.83 \%$ compared with $5.9 \pm 0.48 \%)$. In the only year (1989) when the average prevalence was higher in fishery areas compared with farmed sites, the results are based on just a few farm samples and a greater number of samples from wild stocks from the Fal at a time when there was a steady increase in prevalence of the disease in these stocks (see below). There was no obvious trend in prevalence over time.
Harbour were also infected with Bonamia ostreae at a low level of prevalence (1-2\%). Subsequent sampling within this zone detected presence of $B$. ostreae in oysters from the River Lynher at $10 \%$ prevalence in 1996. The other 2 areas within this designated infected zone from which samples have been obtained are the Rivers Fowey and Yealm. B. ostreae has never been detected in oysters from these areas from 10 and 2 annual samples of 30 oysters, respectively.

The major oyster fishery in southwest England, and the second largest in the UK, is the Truro Fishery in the River Fal. It is unique within the British Isles in that no mechanically propelled vessels are permitted to participate in the fishery. As can be seen in Fig. 2, there has been a significant decline in the prevalence of the Bonamia ostreae parasite during the 1993-2007 monitoring period $\left(\mathrm{r}^{2}=0.76, \mathrm{p}<0.0001, \mathrm{df}=13\right.$; using arcsine-transformed data). Prior to this period, preva-

\section{The River Fal}


Table 3. Sampling and prevalence of Bonamia (\%) by year, 1982 to 2012. Farm: farm site; Fishery: fishery site. -: no samples

\begin{tabular}{|c|c|c|c|c|c|c|}
\hline \multirow{2}{*}{ Year } & \multirow{2}{*}{$\begin{array}{l}\text { Oysters } \\
\text { sampled }\end{array}$} & \multirow{2}{*}{$\begin{array}{l}\text { Sites } \\
\text { tested }\end{array}$} & \multirow{2}{*}{$\begin{array}{c}\text { Sites } \\
\text { positive }\end{array}$} & \multicolumn{3}{|c|}{ - Prevalence } \\
\hline & & & & Overall & Farm & Fishery \\
\hline 1982 & 1964 & 40 & 10 & 2.44 & 9.25 & 0 \\
\hline 1983 & 6051 & 51 & 27 & 8.10 & 14.17 & 2.18 \\
\hline 1984 & 4215 & 39 & 20 & 8.16 & 11.10 & 0 \\
\hline 1985 & 1174 & 9 & 8 & 5.62 & 9.10 & 3.38 \\
\hline 1986 & 3068 & 25 & 16 & 3.88 & 12.79 & 1.59 \\
\hline 1987 & 3075 & 26 & 23 & 11.48 & 12.17 & 4.25 \\
\hline 1988 & 3795 & 36 & 25 & 14.73 & 22.79 & 6.22 \\
\hline 1989 & 1406 & 13 & 10 & 3.70 & 3.07 & 5.45 \\
\hline 1990 & 4572 & 22 & 19 & 6.08 & 10.47 & 5.73 \\
\hline 1991 & 720 & 7 & 2 & 2.83 & 8.50 & 1.70 \\
\hline 1992 & 1500 & 10 & 10 & 5.43 & 7.55 & 4.02 \\
\hline 1993 & 11700 & 78 & 33 & 15.22 & 17.59 & 12.71 \\
\hline 1994 & 8850 & 58 & 29 & 11.10 & 14.46 & 8.38 \\
\hline 1995 & 1680 & 55 & 25 & 13.40 & 21.60 & 7.93 \\
\hline 1996 & 2010 & 66 & 25 & 16.00 & 22.08 & 9.42 \\
\hline 1997 & 2160 & 72 & 21 & 9.52 & 10.50 & 8.64 \\
\hline 1998 & 1950 & 65 & 28 & 13.52 & 20.48 & 4.24 \\
\hline 1999 & 1410 & 47 & 27 & 14.37 & 18.88 & 7.82 \\
\hline 2000 & 1620 & 55 & 30 & 10.99 & 14.56 & 5.63 \\
\hline 2001 & 1620 & 54 & 34 & 9.35 & 12.50 & 5.81 \\
\hline 2002 & 1590 & 53 & 22 & 10.36 & 13.39 & 5.99 \\
\hline 2003 & 1650 & 55 & 28 & 15.72 & 20.24 & 10.50 \\
\hline 2004 & 1767 & 57 & 32 & 9.87 & 12.37 & 7.66 \\
\hline 2005 & 1600 & 50 & 27 & 7.72 & 8.31 & 6.86 \\
\hline 2006 & 1302 & 51 & 27 & 12.00 & 12.26 & 11.79 \\
\hline 2007 & 1419 & 46 & 23 & 8.13 & 13.84 & 6.50 \\
\hline 2008 & 330 & 10 & 5 & 8.12 & 8.30 & 8.00 \\
\hline 2009 & 363 & 5 & 2 & 3.83 & 3.83 & - \\
\hline 2010 & 201 & 2 & 1 & 8.33 & 8.33 & - \\
\hline 2011 & 705 & 8 & 8 & 9.51 & 11.20 & 5.73 \\
\hline 2012 & 840 & 10 & 5 & 9.17 & 10.67 & 1.67 \\
\hline
\end{tabular}

lence had increased steadily from $0.75 \%$ in 1985 , when it was first detected in wild stocks, 3 yr after being found in relayed (cultivated) oysters, to a maximum of $15.2 \%$ in 1990 . There were no samples in 1991 and prevalence was $7.2 \%$ in 1992.

Data on intensity of infection in individual oysters were only recorded from the period 2003-2007 inclusive. During this time of low prevalence of infection, at an average of $2 \%$, nine 30 oyster samples returned a bonamiasis-positive result for a total of 12 oysters. Most $(8 ; 67 \%)$ of these oysters were lightly infected (Grade 1), with 2 oysters in each of the moderately and heavily infected categories (Grades 2 and 3, respectively).

\section{Southern England (Areas 9-15)}

The main fishery here is the Solent, which encompasses managed fisheries of over 17500 ha. The South Coast harbours (Portsmouth, Langstone

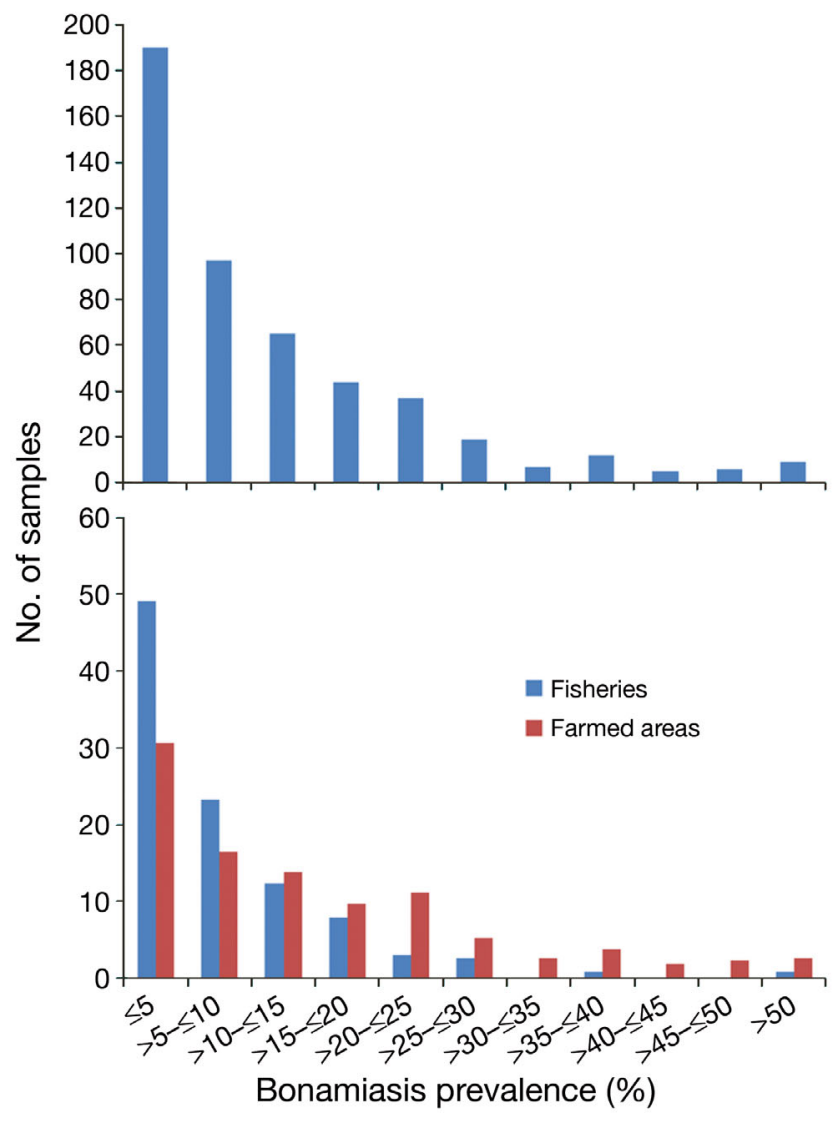

Fig. 1. Distribution of prevalence of Bonamia infection (\%) in all samples with at least one infected animal. (A) All samples; (B) by area type

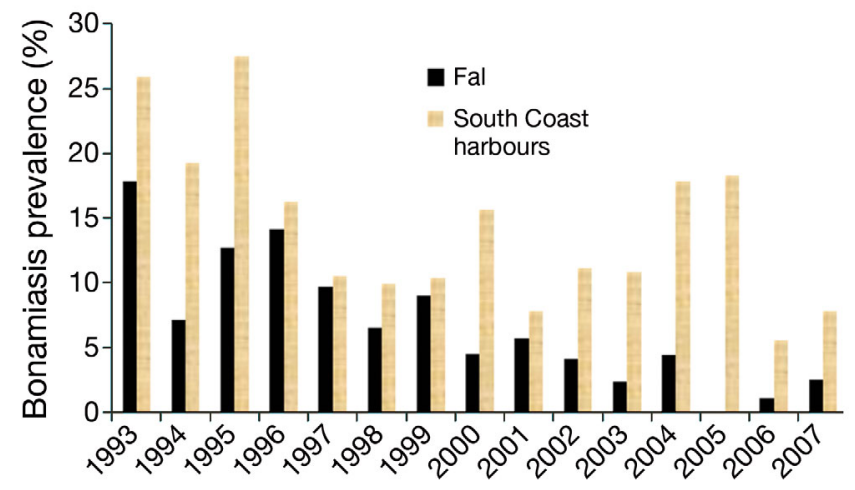

Fig. 2. Mean prevalence of bonamiasis at regularly monitored sites in 2 fishery areas in England (Fal and South Coast harbours) from 1993 to 2007

and Chichester) are public fisheries, although they are covered by local fishery bylaws. In 1991, bonamiasis was known to occur throughout the zone, with the exception of Portsmouth and Langstone harbours, where it was first detected when monitoring began in 1993. 


\section{Solent}

The prevalence of bonamiasis has always been extremely low in these managed fisheries. In $21 \mathrm{yr}$ of sampling (first sample in 1986 and none from 2008 onwards), oysters were taken from several beds in the fishery each year during the main monitoring period 1993-2007 to give a total of over 221 samples over the entire time period; Bonamia ostreae has been confirmed in only 13 of these samples. These positive samples cover 6 of the years in the main programme and the 2 immediate prior years (1991 and 1992), and the average prevalence for these years is $0.6 \%$. Positive samples were obtained in only 3 of the years when intensity of infection was being measured (2003-2007) and has tended to be low. Of the 7 infected oysters from this period, 4 were lightly infected (Grade 1), one moderately infected (Grade 2) and 2 heavily infected (Grade 3 ).

\section{Chichester, Langstone and Portsmouth Harbours}

The prevalence of bonamiasis in the fisheries in these areas is higher than in the wider Solent, with average prevalence during the 1993-2007 period being $12.1 \%$ in Chichester Harbour, 9.1\% in Langstone Harbour and 5.6\% in Portsmouth Harbour. Consistent with the data from the Fal, and taking data from sites with results for each year, there is an overall significant decline in level of infection from 1993 to $2007\left(\mathrm{r}^{2}=0.37, \mathrm{p}=0.017\right.$, df $=13$; using arcsine-transformed data) as shown in Fig. 2. In the $10 \mathrm{yr}$ prior to the main monitoring period there were only 21 samples in total from the 3 sites, with 8 positive samples at an average of $8.9 \%$ prevalence.

\section{Poole and the Fleet}

These areas have only very small-scale fisheries, together with some cultivation. The average production of Ostrea edulis from Poole Harbour was about $13 \mathrm{t}$ per annum during the period 1993-2008. The average level of infection with bonamiasis here is about $16 \%$. In Poole Bay, bonamiasis was detected just once in 1999 during the main (1993-2007) monitoring period from a total of 22 annual samples, at a prevalence of $15 \%$. Prior to this there were just 2 samples taken that gave positive results, one at $2.5 \%$ prevalence in 1986, and one at $3 \%$ prevalence in 1988.
In the Fleet lagoon, 2 samples in 1993 showed an average prevalence of $15 \%$. There were no further attempts at cultivation here until 2003, when hatchery-reared Ostrea edulis juveniles from an uninfected area were introduced. There was high mortality $(>35 \%)$ in this stock within a few months and analysis of samples showed bonamiasis at a prevalence of just less than $30 \%$.

Overall, the average annual prevalence of bonamiasis in fisheries in southern England, at 3.6\%, is lower than that in southwest England (5.8\%) and southeast England (6.6\%), but the differences are not significant $\left(F_{2,43}=1.3, \mathrm{p}=0.281\right)$.

\section{Southeast England (Areas 4-7)}

Low (usually less than 1\%) prevalence in the native oyster stocks in the Solent allows a small cultivation industry to survive in the Essex creeks and estuaries of relaying part-grown oysters taken from this fishery for cultivation to market size in a single growing season. The measured prevalence of Bonamia typically reaches $10-30 \%$ in these oysters in this time, with usually relatively low levels of mortality of less than $15 \%$, although this is not documented.

The main area of activity is in the Blackwater estuary and river, where average prevalence of infection in farms during the main 1993-2007 monitoring period, at $22.2 \%$ from 87 samples, was much higher than that in the wild fisheries, at $9.7 \%$ from 45 samples.

Results from the Blackwater are higher than the national average results of $17.02 \%$ at farms and $4.7 \%$ in fisheries during this period. Indeed the annual average prevalence of bonamiasis at all farms in southeast England is $18.4 \%$, significantly higher than from the other 2 main growing zones (southwest England, $10.8 \%$; southern England, $14.6 \% ; F_{2,42}=$ 4.25, $\mathrm{p}=0.021$ ).

The average prevalence of Bonamia at fishery sites in the Blackwater in the years since 2002, when the nuclear power station ceased to operate, is $12.75 \%$, significantly greater than that prior to 2002 , at $5.45 \%$. Prevalence in farms is broadly similar for the 2 periods, at 21.0 and $22.9 \%$, respectively. In the rest of the UK there is no corresponding trend in bonamiasis prevalence at either fishery or farm sites.

There are 4 separate farm sites, 2 in each of 2 areas (Walton Backwaters [Area 4] and River Blackwater [Area 6]) in the southeast of England, where autumn (September-December) samples were taken every year during the 1993-2007 monitoring period. Exam- 
ination of the results from these sites shows that bonamiasis prevalence is highest in October, declining thereafter. Annual averages are 16.4\% (September), 36.2\% (October), $27.4 \%$ (November) and 19.6\% (December), and the difference between months is significant $\left(F_{3,52}=6.14, \mathrm{p}=0.0011\right.$; using arcsinetransformed data). The intensity of infection (61\% at Grade 3) is also significantly higher in parasitized oysters in October $\left(F_{3,13}=5.42, \mathrm{p}=0.012\right.$; using arcsine-transformed data) in the farm samples. Intensity of infection at Grade 3 in the other autumn sampling months was $37.6 \%$ (September), $43 \%$ (November) and $27 \%$ (December).

There is no equivalent seasonal relationship in fished beds, where prevalence is lower. The intensity of infection in oysters found in the fishery samples is also lower than in the farm samples. Overall, 34\% of fishery oysters were heavily infected (Grade 3) compared with $43 \%$ for farmed oysters.

The 2 adjacent farm sites in Walton Backwaters (Area 4) were sampled on the same date in any one year in 12 of the years during the 1993-2007 monitoring period. The mean prevalence of infection was similar (22.6 and $24.7 \%$ ) at the 2 sites, although the range varied from 0 to $46.9 \%$ at one site and from 3 to $42.4 \%$ at the other. A paired $t$-test detected no correspondence of annual percentage prevalence levels between the 2 sets of results $(t=0.41, \mathrm{p}=0.34$, $\mathrm{df}=$ 11; using arcsine-transformed data).

\section{Spread to new areas}

Samples from the uninfected areas in the UK tested negative until bonamiasis was detected in Northern Ireland for the first time in 2005 and in Scotland and Wales for the first time in 2006. In the 7 yr since 2005, bonamiasis has been detected in Ostrea edulis in 7 new areas in England, Scotland, Wales and Northern Ireland (Table 4).

In all cases, appropriate measures have been put in place to prevent further spread of the disease from these areas (confirmed designations; Fig. 3). These measures prohibit the movement of stock out of the area for relaying or depuration into any area free of the specified pathogen.

In February 2011, analysis of a sample of weak native oysters reportedly harvested from the River Fal and held in purification tanks showed, by molecular methods (Narcisi et al. 2010), that one of these oysters was infected with Bonamia exitiosa. This diagnosis was confirmed by the Ifremer European Union Reference Laboratory for molluscan
Table 4. Spread of bonamaisis in the UK since 2005 (numbers refer to areas in Fig. 3). Initially (1982-1986) the disease was confined to 3 zones represented by Areas 4-7, 9-15 and $17-22$

\begin{tabular}{ll} 
Year & Bonamiasis detected \\
\hline 2005 & $\begin{array}{l}\text { Lough Foyle (on the border between the Republic } \\
\text { of Ireland and Northern Ireland and as such falls } \\
\text { under the jurisdictional control of both Ireland } \\
\text { and the UK) (Area 27) } \\
\text { River Cleddau and Milford Haven, southwest } \\
\text { Wales (Area 24) }\end{array}$ \\
2006 & $\begin{array}{l}\text { Loch Sunart, western Scotland (Area 28) } \\
\text { North Kent (the area affected is contiguous with } \\
\text { previously infected Areas 4-7 (Area 8) } \\
\text { West Loch Tarbert, western Scotland (Area 29) }\end{array}$ \\
2008 & $\begin{array}{l}\text { Strangford Lough, Northern Ireland (Area 30) } \\
\text { Menai Strait, north Wales (Area 25) }\end{array}$ \\
2011 &
\end{tabular}

shellfish diseases. Subsequent sampling of 150 oysters from this fishery and 150 oysters from the adjacent River Helford failed to detect any further $B$. exitiosa positive samples, although $B$. ostreae was detected. Since then all bonamiasis positive oysters have been subjected to PCR testing for $B$. exitiosa, but no further positive samples have been found in the UK.

\section{DISCUSSION}

Bonamiasis, caused by the protozoan parasite Bonamia ostreae, appeared in the UK in 1982 and soon became established in 3 coastal zones. It then did not spread to any new areas in the UK for $19 \mathrm{yr}$ (1986-2005), but thereafter 7 outbreaks followed in as many years. A corresponding pattern in the spread of the disease has been noted in Ireland, where between 1993 and 2002 B. ostreae was not detected in any new areas but was then identified in Achill Sound and in the following year in the nearby beds at Loughmore, Blacksod Bay. In Norway, $B$. ostreae was detected for the first time in 2008 (Hellberg \& Aakvik 2010). Other serious shellfish diseases have also appeared for the first time in England in the last $2 \mathrm{yr}$, including the new variant oyster herpes virus in Pacific oysters and B. exitiosa in Ostrea edulis (Oidtmann et al. 2011). The latter is also associated with the dredge oyster $O$. chilensis, a species that has been introduced to the UK. The strict quarantine procedures used for this introduction make it impossible that this pathway was the source of the pathogen and the actual mechanism is unknown. 


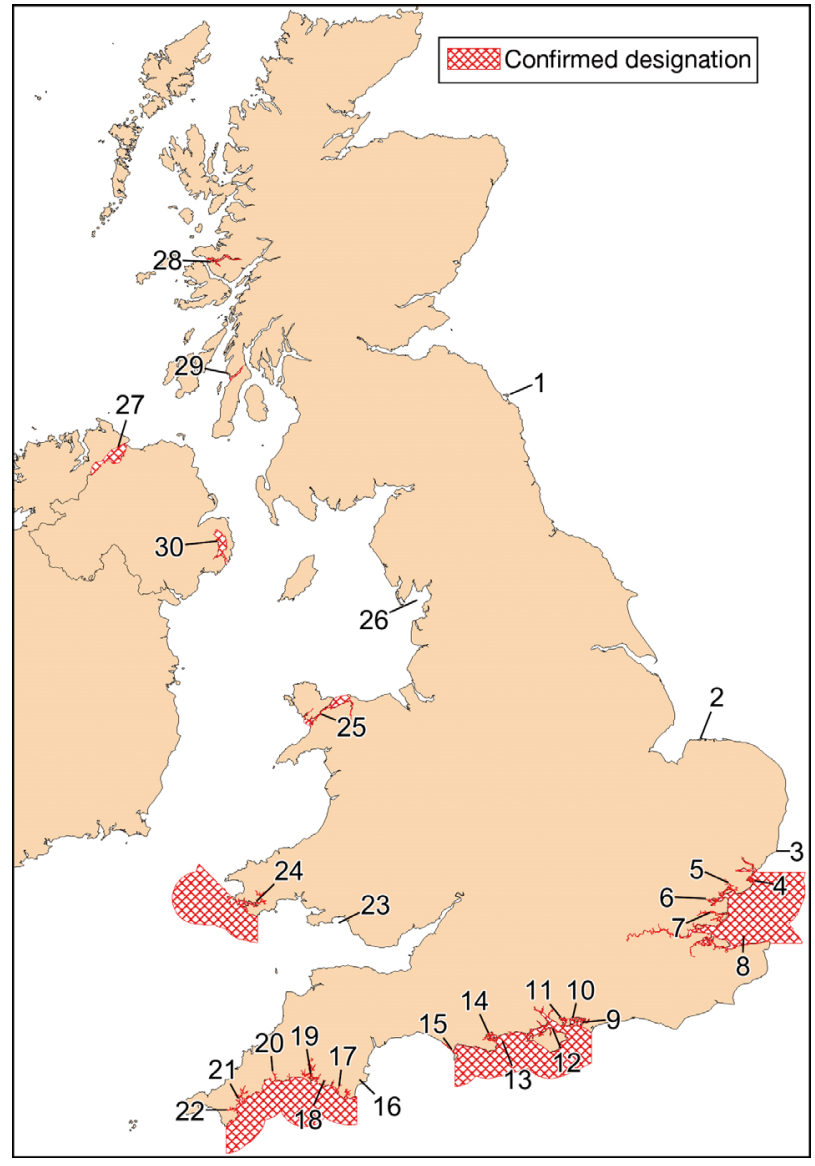

Fig. 3. Confirmed designations for Bonamia ostreae in the UK on 31 December 2012. The figure includes the one area (21) in southwest England where $B$. exitiosa was also detected. Numbers refer to areas listed in Tables $2 \& 4$

It is not clear why bonamiasis should have spread in this way in recent years. Where new outbreaks have occurred, epidemiological investigations have been carried out. These are constrained by the fact that it is rarely clear when the disease was introduced to a new area. It is possible for the parasite to be present at levels that are so low that they are difficult to detect and do not cause any obvious mortality, especially where stock densities are low. This is shown by the small proportion of positive samples from the Solent during routine monitoring. Assuming a perfect test and a prevalence of $5 \%$, there is a $21 \%$ probability that a sample of 30 oysters will fail to detect at least one infected animal. Thus the results presented in this paper probably overestimate the prevalence at infected sites (since low prevalence sites are more likely to be found negative) and underestimate the number of infected sites.
During the initial spread of the disease in England, infection did not appear in some new areas until $4 \mathrm{yr}$ after the last movement of stock from infected areas (Hudson \& Hill 1991). Nevertheless, some ideas of how the disease may have been spread more recently have emerged. These include: unauthorised movement of shellfish; transfer by contaminated fishing vessels or gear; shipping transfers through ballast water discharge or biofouling on boat hulls; and transfer by introduction of marine substrate (ICES 2005).

The most likely source of infection in at least one of the outbreaks in the UK is thought to be the unauthorised deposit of oysters from an infected area. This may have been for the purposes of depuration, when either water from tanks in which the infected oysters were held or the oysters themselves were released into the local environment. For the industry, a primary concern is shellfish hygiene classification, and there can often be a lack of awareness of shellfish health issues and the controls applied to prevent the introduction and spread of bonamiasis. Recent legislation (EC Directive 2006/88/EC) includes a requirement for depuration centres to be authorised and to comply with specific biosecurity measures, which should help to limit the possibility of such events occurring in the future.

Previous epidemiological investigations into incidences of bonamiasis have cited movements of shellfish dredgers as a possible cause of infection (Van Banning 1991). In some of the UK outbreaks, fishing vessels operated in both infected and disease-free areas. Despite the awareness of the risk and guidelines that the vessels are regularly washed down thoroughly between fishing trips, accidental transfer by this means may have occurred.

During the initial spread of the disease in the UK it was suggested that bonamiasis was transferred from positive to negative areas of the south coast of England by infected shellfish on the hulls of boats (Howard 1994). It is also suggested that Bonamia sp. parasites can be introduced through ballast water discharge (Bishop et al. 2006). Whilst there has been no direct evidence of these transfer methods in any of the recent outbreaks, some of the outbreaks are in areas close to busy waterways and major ports, and it is possible that bonamiasis may have been carried into these waters by one of these means.

Where marine gravel transfer takes place, there is the possibility that bonamiasis could be carried within this substrate material, either by direct transfer or from later release of residual material left in the hold. Various organisms other than can Ostrea edulis 
carry the Bonamia parasite. These include 8 benthic macro-invertebrates, for example the brittle star Ophiothrix fragilis (Lynch et al. 2007), and if these or infected oysters are included in the dredge material, then this method of transfer is possible and could apply to at least one of the UK outbreaks. It should also be noted that if commercially cultivated shellfish species such as Pacific oysters and mussels are contaminated with any other organisms capable of carrying the parasite, then legal deposits of these species from infected to disease-free areas can introduce bonamiasis. It has also been suggested that Pacific oysters themselves may transfer the disease organism (Culloty et al. 1999).

It is generally agreed that there is a rising trend in seawater temperatures due to climate change. Seasurface temperatures in UK coastal waters have risen by between 0.2 and $0.8^{\circ} \mathrm{C}$ per decade since the 1980s, and warming in the shelf seas around UK and the upper layers of the North Atlantic is predicted to continue (rising by 1.5 to $4^{\circ} \mathrm{C}$; Lowe et al. 2009), although perhaps at a lesser rate to that observed in the last 25 yr (Hughes et al. 2010). The potential effect of this on the spread and prevalence of bonamiasis should therefore be examined. Such information is currently limited. Arzul et al. (2009) showed that parasite survival and non-specific esterase activities were lower at higher temperatures $\left(25^{\circ} \mathrm{C}\right)$ than at 4 or $15^{\circ} \mathrm{C}$. Our data from the Blackwater show that prevalence of bonamiasis in wild oysters was lower during the period when water temperatures were raised by the power station effluent, although unfortunately we do not have temperature records as readings from the nearest routine monitoring station at Bradwell are only available up until 2002. There is also a measurable decrease in bonamiasis prevalence in the 2 areas in the UK (Fal and South Coast harbours) most likely affected by naturally increasing seawater temperatures. However, Hauton et al. (1998) found that immuno-competence of oysters was best at intermediate $\left(15^{\circ} \mathrm{C}\right)$ temperature, provided salinity was high, and Engelsma et al. (2010) found evidence suggesting that mortality in flat oysters increased at higher water temperatures. So although prevalence of the disease may be lower at higher temperatures, the oysters may be more likely to die.

Salinity is also a factor in prevalence of disease. Arzul et al. (2009) found that high salinities $\left(\geq 35 \mathrm{~g} \mathrm{l}^{-1}\right)$ favoured survival of the Bonamia ostreae parasite. In the eastern USA, results show statistically significant correlations between the observed prevalence of Haplosporidium nelsoni (multinucleated sphere $\mathrm{X}$ disease, MSX) in Crassostrea virginica and multiple physical factors including salinity (Wang et al. 2012).

A further factor in decreasing prevalence of bonamiasis in fisheries in the Fal and South Coast harbours may be development of resistance to the disease within these stocks. There is clear evidence from other studies to show that Ostrea edulis stocks can become disease resistant (e.g. Elston et al. 1987, Culloty et al. 2004, Da Silva et al. 2005). Development of resistance to an introduced pathogen by native oyster stocks has also clearly been shown for the eastern oyster Crassostrea virginica infected with MSX in Delaware Bay, USA (Ford \& Bushek 2012). Since 2005, oyster stocks in the Fal have recovered to levels greater than those prior to the detection of bonamiasis in this area (Vanstaen 2012).

Landings data from managed fisheries are available but do not necessarily reflect prevalence of disease in stocks due to variation in other factors, especially fishing effort. Landings from the River Fal fishery were $120-250 \mathrm{t} \mathrm{yr}^{-1}$ in the years immediately preceding the first records of bonamiasis in this area in 1982. Landings were then very much reduced from 1983 to 1992, at an average of less than $20 \mathrm{t} \mathrm{yr}^{-1}$, almost certainly due to the mortalities inflicted by the disease and the effect this will have had on recruitment. There was a revival in catches in the mid to late 1990s, at a time of decreasing prevalence of bonamiasis (Fig. 2), to around $100 \mathrm{t} \mathrm{yr}^{-1}$. However, landings have reduced again since then.

Stock densities on exploited oyster grounds can be variable due to a combination of year-on-year differences in fishing effort and irregular recruitment due to environmental factors. Although prevalence of bonamiasis in the Solent remains low, population surveys show a trend of decline in oyster stocks and very limited recruitment (Vanstaen \& Palmer 2009). Van Banning (1991) and Engelsma et al. (2010) found no relationship for prevalence of bonamiasis and oyster stock densities in The Netherlands, and the former concluded that the level of prevalence is related to various stress factors.

There has been no decline in prevalence of bonamiasis in cultivated stocks in the UK during the period of this study. A range of mechanical (e.g. handling and sorting) and biological (e.g. food availability, salinity, stock density) stress factors may be important. This is clearly illustrated by the lack of any relationship between the prevalence of bonamiasis in cultivated stocks at 2 adjacent sites in southeast England. Year-on-year variation within and between individual farm sites may depend on 
cultivation practices employed such as size, quantity and time that seed or half-grown oysters become available and density at which they are relayed. Such practices are often not under the control of the operator and lack of documentation makes it difficult to identify specific reasons for variation in prevalence.

In this study bonamiasis prevalence was highest in October. By contrast, in The Netherlands, annual monitoring of fishery sites (1989 to 2006) indicated that prevalence was highest in the largest oysters in spring and declined disproportionately in autumn (Engelsma et al. 2010). This may be due to high mortality of large oysters before autumn, suggesting that prevalence depends on oyster age. Lower prevalence in UK oysters in November and December may be due to loss of stock through mortality due to the disease earlier in the year. Experience from studies in Spain (Cigarria et al. 1995) suggests that holding oysters into another year gives very little additional yield attributable to growth, as mortality increases to $75-90 \%$.

\section{CONCLUSIONS}

Bonamiasis has spread to several new areas in recent years, but it is not clear why this should have happened. Outbreaks are practically impossible to trace and there are various pathways, some of which are difficult to monitor and control. In some managed fishery areas the prevalence of the disease is declining. This may be due to rising seawater temperatures and/or an element of resistance in the stocks. Prevalence of the disease in cultivated stocks is variable, similar to that when the disease was first introduced and with no discernible pattern or obvious relationship with any particular biotic or abiotic factors. There is a lack of information on specific farm management practices that will confound the prevalence data. In the UK, prevalence in cultivated stocks is highest in October.

Acknowledgements. This study would not have been possible without the cooperation and assistance of the UK shellfish industry in supplying oyster samples over many years, and the contribution of numerous field and laboratory staff of the official services collecting and testing these samples. We also acknowledge the help of Cefas colleagues Michael Gubbins and Owen Morgan in the preparation of this manuscript. Support of the Department for Environment, Fisheries and Rural Affairs (Defra) (contract FB002) is also gratefully acknowledged. () Crown copyright (2013). Reproduced with the permission of the Controller of Her Majesty's Stationery Office/Queen's Printer for Scotland and Cefas.

\section{LITERATURE CITED}

Alderman DJ (1979) Epizootiology of Marteilia refringens in Europe. Mar Fish Rev 41:67-69

> Arzul I, Gagnaire B, Bond C, Chollet B and others (2009) Effects of temperature and salinity on the survival of Bonamia ostreae, a parasite infecting flat oysters Ostrea edulis. Dis Aquat Org 85:67-75

> Bishop MJ, Carnegie RB, Stokes NA, Peterson CH, Burreson EM (2006) Complications of a non-native oyster introduction: facilitation of a local parasite. Mar Ecol Prog Ser 325:145-152

Cigarria J, Fernandez JM, Lopez M (1995) Viabilidad del cultivo de la ostra plana (Ostrea edulls L.) en la Ria del Eo (Asturies, N Espana). Iberus 13:1-8

Culloty SC, Novoa B, Pernas M, Longshaw M, Mulcahy MF, Feist SW, Figueras A (1999) Susceptibility of a number of bivalve species to the protozoan parasite Bonamia ostreae and their ability to act as vectors for this parasite. Dis Aquat Org 37:73-80

Culloty SC, Cronin MA, Mulcahy MF (2004) Potential resistance of a number of populations of the oyster Ostrea edulis to the parasite Bonamia ostreae. Aquaculture 237:41-58

Da Silva PM, Fuentes J, Villalba A (2005) Growth, mortality and diseases susceptibility of oyster Ostrea edulis families obtained from brood stocks of different geographical origins, through on-growing in the Ria de Arousa (Galicia, NW Spain). Mar Biol 147:965-977

Diggles BK, Cochennec N, Hine PM (2003) Comparison of diagnostic techniques for Bonamia exitiosus from flat oysters Ostrea chilensis in New Zealand. Aquaculture 220:145-156

- Elston RA, Kent ML, Wilkinson MT (1987) Resistance of Ostrea edulis to Bonamia ostreae infection. Aquaculture 64:237-242

Engelsma MY, Kerkhoff S, Roozenburg I, Haenen OLM and others (2010) Epidemiology of Bonamia ostreae infecting European flat oysters Ostrea edulis from Lake Grevelingen, The Netherlands. Mar Ecol Prog Ser 409:131-142

> Ford SE, Bushek D (2012) Development of resistance to an introduced marine pathogen by a native host. J Mar Res 70:205-223

> Gomori G (1950) A rapid one-step trichrome stain. Am J Clin Pathol 20:661-664

Hauton C, Hawkins LE, Hutchinson S (1998) The use of the neutral red retention assay to examine the effects of temperature and salinity on haemocytes of the European flat oyster Ostrea edulis (L). Comp Biochem Physiol B 119: 619-623

Hellberg H, Aakvik K (2010) The surveillance and control programme for bonamiosis and marteiliosis in European flat oysters (Ostrea edulis L.) in Norway. In: Brun E, Jordsmyr HM, Hellberg H, Sviland S (eds) Surveillance and control programmes for terrestrial and aquatic animals in Norway. Annual Report 2008. National Veterinary Institute, Oslo, p 1-14

Howard AE (1994) The possibility of long distance transmission of Bonamia by fouling on boat hulls. Bull Eur Assoc Fish Pathol 14:211-212

> Hudson EB, Hill BJ (1991) Impact and spread of bonamiasis in the UK. Aquaculture 93:279-285

Hughes SL, Holliday NP, Kennedy J, Berry DI and others (2010) Temperature (air and sea) in MCCIP Annual Report Card 2010-11. MCCIP Science Review, available at www.mccip.org.uk/arc 
ICES (2005) Vector pathways and the spread of exotic species in the sea. ICES Cooperative Research Report No. 271. International Council for the Exploration of the Sea, Copenhagen

Lowe JA, Howard T, Pardaens A, Tinker J and others (2009) UK climate projections science report: marine and coastal projections. Met Office Hadley Centre, Exeter

Lynch SA, Armitage DV, Coughlan J, Mulcahy MF, Culloty SC (2007) Investigating the possible role of benthic macroinvertebrates and zooplankton in the life cycle of the haplosporidian Bonamia ostreae. Exp Parasitol 115: 359-368

Narcisi V, Arzul I, Cargini D, Mosca F and others (2010) Detection of Bonamia ostreae and B. exitiosa (Haplosporidia) in Ostrea edulis from the Adriatic Sea (Italy). Dis Aquat Org 89:79-85

Oidtmann BC, Thrush MA, Denham KL, Peeler EJ (2011) International and national biosecurity strategies in aquatic animal health. Aquaculture 320:22-33

OIE (World Organisation for Animal Health) (2011) WAHID

Editorial responsibility: Marc Engelsma,

Lelystad, The Netherlands database, immediate notifications and follow-ups - 2011; infection with Marteilia refringens in the United Kingdom. OIE, Paris

OIE (World Organisation for Animal Health) (2012) Infection with Bonamia ostreae. In: Manual of diagnostic tests for aquatic animals 2012. OIE, Paris, p 463-474

- Van Banning P (1991) Observations of bonamiasis in the stock of the European flat oyster, Ostrea edulis, in the Netherlands, with special reference to recent developments in Lake Grevelingen. Aquaculture 93:205-211

Vanstaen KR (2012) Truro oyster fishery: oyster stock survey, 28 Feb-1 March 2012. Cefas Shellfish Resource Team Report 92, Cefas, Lowestoft

Vanstaen KR, Palmer D (2009) Solent regulated fishery oyster stock survey, 16-22 June 2009. Cefas Shellfish Resource Team Report No. 83, Cefas, Lowestoft

Wang Z, Haidvogel DB, Bushek D, Ford SE, Hofmann EE, Powell EN, Wilkin J (2012) Circulation and water properties and their relationship to the oyster disease MSX in Delaware Bay. J Mar Res 70:279-308

Submitted: February 18, 2013; Accepted: July 28, 2013

Proofs received from author(s): November 15, 2013 